\title{
THE ENTOMOLOGIST
}

Vor. XXXII.] SEPTEMBER, 1899.

[No. 436.

oN THE NOMENCLATURE OF THE RHYNChOTA.-Part 1.

By G. W. Kirkaldy.

Young entomologists commencing the study of the Rhynchota are doubtless often discouraged, when extending their labours beyond British forms, by the chaotic condition of the nomenclature; although the specific names are fairly well fixed--as much so as one can expect for artificial conceptions-the generic names seem to have no stability, and one has sometimes to spend more time in hunting up references and working through piles of volumes and pamphlets than in actual examination of the insects themselves.

In some orders, where a very similar condition of things prevails, there is good excuse, as, for example, in the Lepidoptera, where the leading authorities are not at all in accord as to whether certain works are to be accepted or not. In the Rhynchota there appears to be (except in a few isolated cases) no such excuse whatever. I have carefully examined all the literature of the Heteroptera (of which I am cognisant), up to 1810 , and I know of two genera only in which the type cannot be indubitably fixed, according to the strict law of priority.

I am aware that with many men it is the custom to sneer at what are termed "antiquarian researches," but I am convinced that, until the nomenclature of the genera is tolerably well and safely fixed, anatomical and biological investigations can only be conducted with an unnecessary amount of extraneous trouble.

O. M. Reuter has already, in a monumental work, ${ }^{*}$ settled definitely a great number of genotypes, and although in a few cases I find his results open to question-and these are when he

* " Revisio synonymica Heteropterorum palæarcticorum, \&c.," in 'Acta Soc. Sci. Fennicæ,' 1888, xv. pp. 241-313 and 443-812.

ENTOM.-SEPTEMBER, 1899. 
has avoided the strict application of the rule-my researches convince me that his main conclusions are perfectly correct. It would have been unnecessary to make such a remark, were it not that three important works by serious rhynchotists* have been published (subsequent to the 'Revisio'), in whichReuter's results have been almost entirely ignored.

In consulting these works, moreover, I have been unable to appreciate the method by which the names of the families and subfamilies are appropriated; for instance, on p. 45 of Puton's "Catalogue,' the first tribe of the "Reduvides" is given as "Emesini." Why? Is Emesa a more typical genus than Ploiariola or Ploiaria? It seems to me that the only satisfactory and uniform method-in the present state of our knowledge - is to take the genus founded earliest, and form from that the family, \&c., names; i.e., Ploiaria, dating from 1786, is the oldest-in its subfamily-and that subfamily should then be known as Ploiarinas (or tribe Ploiariini). Reduvius, 1775, is the oldest genus in the whole family, so that the latter is, as usually termed, Reduvinde. On the other hand, Miris, 1794, $\dagger$ antedates Capsus, 1803, by nine years, and the family should be known as MIRIDÆ.

1. Linnæus founded in the 'Systema Naturæ,' ed. 10, 1758, three heteropterous genera; viz. Cimex, Nepa, and Notonecta. As the types of the two last (i. e. $N$. cinerea and $N$. glauca) are not disputed, it is unnecessary to dwell upon them. Eightythree species are included in Cimex, but it was not broken up till Fabricius in 1775, 'Systema Entom.,' removed several species to found Acanthia and Reduvius.

The type of Cimex must be among the Linnean species left therein by Fabricius, and cannot therefore be $C$. lectularius, removed by the latter to Acanthia. $\ddagger$

Reuter has indicated personatus, Linn., as the type of Reduvius, Fabr. (Lamarck, 1801), and this seems to be generally accepted. He also indicates zostere, Fabr., and littoralis, Linn., as the types of Acanthia, Fabr., but as this has been accepted neither by Saunders, Leithierry and Severin, nor Puton, nor yet by Horvath, $\S$ it may be worth while to recapitulate the reasons

* Edward Saunders, 1892, 'Hemipt. Heteropt. British Islands'; Lethierry \& Severin, 1893-96, 'Catal. général Hémiptères,' i.-iii. ; A. Puton, 1899, 'Catal. Hémiptères paléarct.,' ed. 4.

† “"1771," by printer's error in the 'Revisio,' pp. 613 and 764 .

+ This result is unaffected by any subsequent type-fixations or new genera; for example, C. lectularius was wrongly fixed by Latreille in 1802 as the type of Cimex. Dr. Reuter remarks (p. 268): "Dass Latreille . . . . für diese Art den Namen Cimex aufnahm, scheint mir nur ein Zeugniss seines guten Tactes zu sein." The learned Doctor is doubtless endowed with a very subtle gift of irony, as I fail to see any display of "tact" in committing an error which has caused nearly a century of nomenclatural confusion, and left the commonest bug without a proper name.

§ 1898, 'A magyar birod állatv. Hemipt.' (1897), p. 43. 
for this step. Acanthia, Fabr., 1775, contained a heterogeneous assemblage, but it was not till 1797 that Latreille indicated littoralis and its congeners as the types of the genus. It is, I think, indisputable that (1) Acanthia was not broken up, nor was any type fixed, till 1797 ; and (2) that Latreille did fix the type. I therefore see no alternative to adopting the name Acanthia for littoralis, \&c., as Reuter has already done in his monograph of the palæarctic species.

For Cimex lectularius, Linn., I now propose the generic name KLINOPHILOs (with genotype lectularius).

From the remnants of Acanthia have been formed, up to 1803, Phymata, Latr., 1802 ; Aradus, Fabr., 1803, of which Reuter has indicated the types; and Tingis, Fabr., 1803, of which Reuter cites "Acanthia pyri, Fabr.," as the type. This is, however, incorrect, T. cardui (Fabr.) having been indicated by the founder of the genus (p. 125).

2. In 1762 Geoffroy erected two genera-Naucoris (type [cimicoides, Geoffr. nec Linn.=] maculata, Fabr.) and Corixa (type [striata, Geoffr. nec Linn. =] geoffroyi, Leach).* Sigara, Fabr. 1775, is synonymous with Corixa, Geoffr.

The next publication was Olivier's contribution, in 1789 , to the 'Encyclopédie Méthodique,' vol. iv. In this precious volume a "new" genus, Pentatoma, was "founded," though very feebly diagnosed, and without mention of species or type.

As the work is, I believe, rare, it may be interesting to some rhynchotists to read the original descriptions :-

“No. 59. Cimex, Linn. Geoffr. Fabr. Acanthia, Fabr.Antennes filiformes, composées de quatre articles très distincts. Trompe recourbée sous la poitrine, creusée en goutière, \& contenant trois soies. Trois articles aux tarses. Corps alongé, rarement ovale, souvent déprimé.

"No. 60. Pentatoma Cimex, Linn. Geoffr. Fabr.-Antennes filiformes, composées de cinq articles cylindriques. Trompe recourbée sous la poitrine, creusée en goutière, \& contenant trois soies. Trois articles aux tarses. Corps souvent ovale."

That is to say, the only workable difference between the two is that Cimex has four-segmented antennæ, Pentatoma five. Fabricius, in 1794 (Entom. Syst. iv.), splits up Cimex into five genera, Cimex itself being reserved for the forms now known as "Pentatomidæ" in the widest sense. Now, if Pentatoma, Oliv., as subsequently fixed by Lamarck in 1801 (note, twelve years after its original proposal), is allowed to be valid, I fail to see how the type of Cimex can be fixed. Pentatoma, Oliv., 1789, if it has any value at all, is equivalent to the "Pentatomidæ" as a

* I do not know why Reuter places Geoffroy's "Histoire abrégée des Insectes " in the first part of his 'Historische Uebersicht,' viz. "Arbeiten, in welchen die binäre Nomenclatur nicht durchgeführt ist "!! 
whole (that is, to Cimex, Fabr., 1794); but Olivier's definitions of the two genera appear to me utterly worthless. Pentatoma was disregarded altogether by Fabricius both in 1794 and 1803, and was considered synonymous with Cimex by Latrielle in 1797 .

The antennæ in the majority of the "Pentatomidæ" have certainly five segments, but a large proportion have only four, and a few three. Moreover, Olivier's definition of Cimex does not accord with that of Fabricius, 1775 (legitimately modified from Linnæus), and does not suffice for the remainder of Fabricius's Cimex after the removal of the "Pentatomidæ." Furthermore, there is no indication of types nor mention of species in either. I propose therefore to treat "Pentatoma, Olivier," as a nomen nudum, and disregard it altogether as a nomenclatural factor at 1789 , but hold it in suspense till 1796 , when it is ranked as a synonym of Cimex by Latrielle.

3. The types of the four genera removed by Fabricius from Cimex in 1794 were fixed by the founder as follows:-

213. Coreus, type scapha (Fabr.).

214. Lygaus, type valgus (Linn.).

215. Miris, type dolobratus (Linn.).

216. Gerris, type lacustris (Linn.).

The first three are not generally accepted.

Coriscus, Schrank, 1796 (type dauci), remains unidentified, but the types of the other genera not previously mentioned, erected between 1786 and 1803, are as indicated by Reuter, except that the type of Cimex is recorded on p. 301 as "nigrideus," whereas it is "bidens, Linn."

The following will demonstrate the synonymy I now propose, which is really almost an entire return to the nomenclature adopted by Stal in the opening volumes of the 'Enumeratio':-

1. Cimex, Linn., 1758. Type, bidens, Linn., Fabr., 1803.

2. Pentatoma, Oliv., 1789. Valueless ranked as syn. of Cimex, 1797.

3. Lygesus, Fabr., 1794=Holopterna, Stål, 1873, and modern authors. Type, valgus (Linn.), Fabr.

4. Tingis, Fabr., $1803=$ Philontochila, Fieb., and modern authors. Type, cardui (Linn.), Fabr.

5. Kuinophilos, Kirkaldy, $1899=$ Cimex of some modern authors=Acanthia of others. Type, lectularius (Linn.), Kirk.

From this follows the synonymy as below :-

1. С̆micidж $=$ Pentatomidæ, auct.

2. LYGжIDÆ $=$ Coreidæ, auct.

2a. Lygæinæ= Mictinæ, auct.

2b. Coreinæ $=$ Centroscelinæ, auct.

3. МчоросніDж = Lygæidæ, auct.

3a. Astacopinæ = Lygæinæ, auct. 
4.* Macrocephalide $=$ Phymatidæ, auct.

5. MIRID $=$ Capsidæ, auct.

6. $-?-=$ Cimicidæ, auct.

I have not thought it necessary to enumerate the changes desirable in a large number of other subfamilies.

\section{THE TYPE OF THE GENUS HYPOLYCENA.}

By A. G. Butler, Ph.D.

IN the 'Wiener Entomologische Monatschrift' for 1860, Felder described a new Lycænid under the name of Myrina thecloides, and, in a footnote, he remarked, "This species and its allies, $M$. erylus, Godt., and $M$. sipylus, Feld., differ from the Myrinas in having the second joint of the palpi shorter than the head, the third long, aciculate, arched, the antennæ moderately clubbed."

In the same Journal, two years later, he refers back to this description (to which he adds that the antennæ are clearly but distantly annulated), and he gives to the group the name Hypolycena, adding to it three additional species.

Now it stands to reason that, $M$. thecloides being the only species to which the original description was referred, the fact that no name for the genus was proposed until 1862, cannot prevent $M$. thecloides being its type, and it is manifestly a blunder to recognize any of the three species referred to as "tribus ulterioribus speciebus" as the type of a description written befere they were received.

Dr. Scudder was the first to fall into error, when he stated that $H$. tharrytas might be taken as the type; whilst, later, Dr. Moore equally incorrectly indicated $H$. tmolus: the latter is indeed congeneric with $H$. thecloides and with $H$. erylus, although it possesses a far better defined male sexual patch on the primaries than either of them.

Without personal critical comparison of all the structural characters, I am not (at present) prepared to accept all the African forms as belonging to the genus: they may do so. 


\section{$2 \mathrm{BHL}$ Biodiversity Heritage Library}

Kirkaldy, George Willis. 1899. "On the nomenclature of the Rhynchota.--Part I." The Entomologist 32, 217-221. https://doi.org/10.5962/bhl.part.3140.

View This Item Online: https://www.biodiversitylibrary.org/item/42961

DOI: https://doi.org/10.5962/bhl.part.3140

Permalink: https://www.biodiversitylibrary.org/partpdf/3140

\section{Holding Institution}

Smithsonian Libraries

\section{Sponsored by}

Smithsonian

\section{Copyright \& Reuse}

Copyright Status: NOT_IN_COPYRIGHT

This document was created from content at the Biodiversity Heritage Library, the world's largest open access digital library for biodiversity literature and archives. Visit BHL at https://www.biodiversitylibrary.org. 